\title{
Cuidando do ursinho: brincar, aprender e desconstruir na educação em saúde
}

\author{
Karen Vieira da Silva, Daniel Demétrio Magalhães, Letícia Kelly Souza Lopes, Luísa Fontes \\ Carvalho, Pedro Paulo de Liz Daher, Debora Carvalho Ferreira
}

\section{Resumo}

A observação dos resultados positivos obtidos nas experiências em 2015 das atividades educativas realizadas com crianças, envolvendo uma "consulta" de um ursinho de pelúcia com acolhimento, orientações sobre higiene e alimentação, exames e curativos permitiu o desenvolvimento de uma ação longitudinal, baseada na educação popular, que reinventasse a relação entre as crianças e os profissionais de saúde, assim como a percepção e os conhecimentos delas acerca dos cuidados à saúde. Permitir que as crianças pudessem ser protagonistas do processo de cuidado e promoção de saúde; Desconstruir o medo infantil da figura do profissional de saúde; Expor as crianças a um espaço de trabalho em equipe, desenvolvendo nelas o multipapel de paciente e profissional de saúde; Aproximar os saberes popular e acadêmico. Com um grupo de 34 estudantes de graduação dos cursos de Medicina, Enfermagem, Nutrição e Pedagogia, foram realizadas atividades educativas semanais, baseadas nos métodos de Educação Popular, na escola Padre Francisco José da Silva da comunidade de Nova Viçosa com 49 crianças de duas turmas do $2^{\circ}$ ano. A primeira etapa foi reconhecimento da comunidade, da UBS, da escola e das crianças. Após esse passo, cada criança ganhou um bicho de pelúcia, com seu respectivo cartão SUS, que recebeu uma "consulta". Ademais, em cada semana era trabalhado um tema, tais quais: "O que é posto de saúde?"; "Conhecendo nosso corpo (órgãos, bullying); " Dengue"; "Atividade física". Foram usados teatro, paródia (Show das dengosas), circuito interativo (caça mosquitos), brincadeiras com bambolê e corda. Buscou-se também associar as atividades ao aprendizado escolar, com noções de lateralidade (esquerda/direita), operações matemáticas e leitura. Dentro da atividade sobre o posto de saúde foi criado um espaço para as crianças dentro da UBS. As crianças relataram inúmeras experiências e as suas impressões, sentimentos e sensações, inclusive, o medo, que foi desconstruído paulatinamente. Elas foram somando seus saberes e desenvolvendo os conhecimentos trabalhados pelas professoras associados com os conhecimentos acerca dos cuidados à saúde. As professoras acompanharam e gostaram das abordagens, inclusive realizaram atividades de cunho escolar com seus alunos, como gráfico matemático sobre o projeto; confecção de uma certidão de nascimento, mini textos sobre como cuidar do ursinho e hábitos de higiene; história em quadrinhos da paródia da dengue, entre outras. As crianças demonstraram muito interesse e participaram de forma ativa em todas as atividades, sendo que em algumas houve dificuldades em abordar determinadas situações. Por ser uma ação longitudinal, sobretudo, que ainda está em continuidade até o final do ano, os integrantes do projeto construíram laços de carinho e empatia com as crianças e, vice-versa, o que facilitou a comunicação entre esses grupos. Outros pontos importantes foram o compartilhamento de experiências com as crianças e o reconhecimento das situações de vulnerabilidade social vivenciadas por elas e da sua carência afetiva. Pode-se inferir que é uma realidade completamente diferente dos integrantes do projeto, tornando necessário despir-se de preconceitos e vestir-se de gentileza, estando aberto para uma nova cultura.

Descritores: Educação de saúde; Saúde da Criança; Promoção de saúde. 